\title{
Cryogenic fracturing of calcite flowstone in caves: theoretical considerations and field observations in Kents Cavern, Devon, UK.
}

\author{
Joyce Lundberg ${ }^{1}$ and Donald A. McFarlane ${ }^{2}$
}

\begin{abstract}
:
Lundberg J. and McFarlane D. 2012. Cryogenic fracturing of calcite flowstone in caves: theoretical considerations and field observations in Kents Cavern, Devon, UK. International Journal of Speleology, 41(2), 307-316. Tampa, FL (USA). ISSN $0392-6672$. http://dx.doi.org/10.5038/1827-806X.41.2.16

Several caves in Devon, England, have been noted for extensive cracking of substantial flowstone floors. Conjectural explanations have included earthquake damage, local shock damage from collapsing cave passages, hydraulic pressure, and cryogenic processes. Here we present a theoretical model to demonstrate that frost-heaving and fracture of flowstone floors that overlie wet sediments is both a feasible and likely consequence of unidirectional air flow or cold-air ponding in caves, and argue that this is the most likely mechanism for flowstone cracking in caves located in Pleistocene periglacial environments outside of tectonically active regions. Modeled parameters for a main passage in Kents Cavern, Devon, demonstrate that 1 to 6 months of -10 to $-15^{\circ} \mathrm{C}$ air flow at very modest velocities will result in freezing of 1 to $3 \mathrm{~m}$ of saturated sediment fill. The resultant frost heave increases with passage width and depth of frozen sediments. In the most conservative estimate, freezing over one winter season of $2 \mathrm{~m}$ of sediment in a 6-m wide passage could fracture flowstone floors up to $\sim 13 \mathrm{~cm}$ thick, rising to $\sim 23 \mathrm{~cm}$ in a 12-m wide passage. Natural flaws in the flowstone increase the thickness that could be shattered. These numbers are quite consistent with the field evidence.
\end{abstract}

Keywords: speleothem; frost heave; periglacial; Kents Cavern; ice; cave; Pleistocene

Received 8 March 2012; Revised 8 May 2012; Accepted 13 June 2012

\section{INTRODUCTION}

At least as far back as the nineteenth century, investigators have noted distinctive cracking in the flowstone floors of certain caves in South West England. Thick calcite flowstones overlying clayrich breccia in Kents Cavern, Devon (Fig. 1), a predominantly horizontal cave with discrete upper and lower entrances, are often cracked into a trellis or reticulate pattern (although only a few examples are now left after the extensive eighteenth century excavations). For example, commenting on his excavation of the Labyrinth Passage of Kents Cavern, MacEnery $(1859$, p. 27$)$ noted that

"... it was floored through its entire extent with a continuous sheet of stalagmite ... so difficult to penetrate that after repeated attempts we abandoned it in despair; at length availing ourselves of cracks that traversed it, like the divisions in a pavement, we succeeded in ripping it up".

${ }^{1}$ Department of Geography and Environmental Studies, Carleton University, Ottawa, ON K1S 5B6, Canada

(joyce_lundberg@carleton.ca)

${ }^{2}$ WM. Keck Science Center, The Claremont Colleges, 925 North Mills Avenue, Claremont CA 91711 USA

(dmcfarla@jsd.claremont.edu)

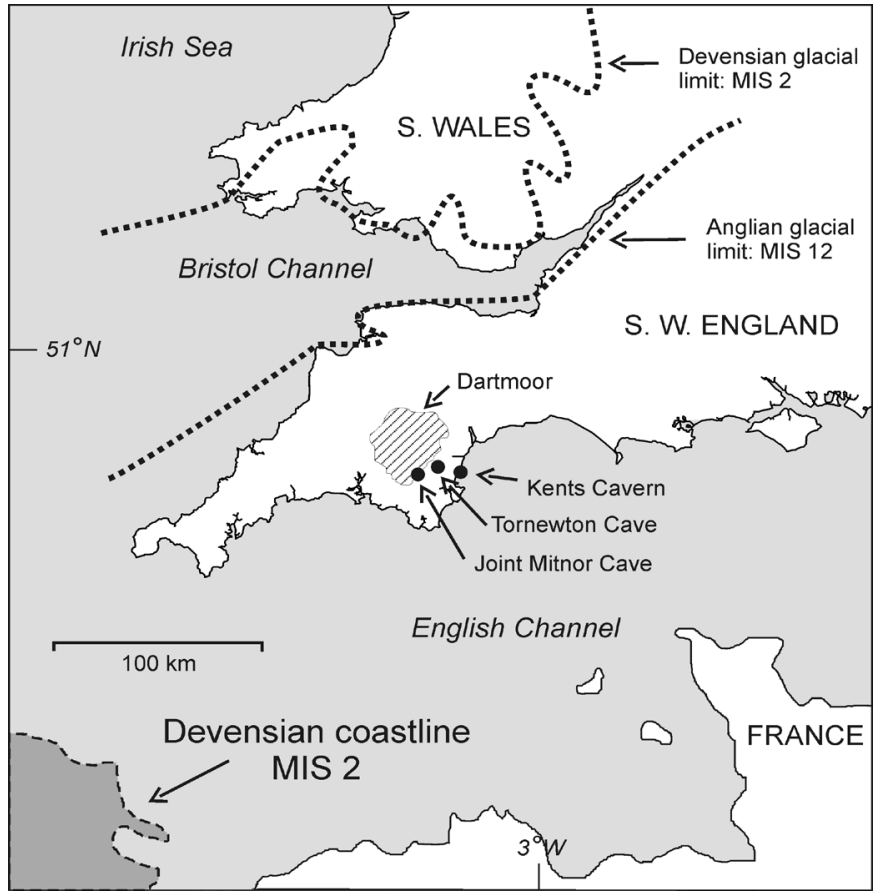

Fig. 1. Location of Kents Cavern, Joint Mitnor Cave, Dartmoor, and glacial limits (after Cullingford, 1982; Croot \& Griffiths, 2001) and coastline at $20 \mathrm{ka}$ (Cambridge University, 2009). 
Pengelly made frequent reference to the sharpedged broken flowstone in many parts of the cave, noting that some blocks were displaced by several inches above their original level, and that some of the fracture blocks had become incorporated into the overlying sediment (Pengelly, 1869; Pengelly, 1884).

A century later, Sutcliffe (1960) drew attention to similar flowstone cracking in Joint Mitnor Cave, an important paleontological site intersected by quarrying at Buckfastliegh, $20 \mathrm{~km}$ from Kents Cavern. Joint Mitnor Cave was an open pit cave during much of the Pleistocene and later infilled. Here a calcite layer, described as shattered and re-cemented flowstone up to $45 \mathrm{~cm}$ thick, overlies loosely-packed bone-bearing sediments and water-laid sediments. Sutcliffe (1960) also reported cracked flowstone overlying sediment in nearby Reed's Cave. In Tornewton Cave, some 20 km to the northwest of Kents Cavern, Sutcliffe \& Zeuner (1962) describe a broken Stalagmite Formation that overlies a Laminated Clay bed as a substantial and probably formerly continuous floor/wall dripstone layer.

The explanations for this cracking have varied. A popular and oft repeated explanation has been an appeal to tectonic activity, either in the form of regional earthquakes or local tremors due to nearby collapsing caves. MacEnery (1859) was the first to suggest tectonic activity as the cause of the extensively cracked flowstone floors of Kents Cavern. Pengelly, in the course of a 15 year excavation of the palaeontological and archaeological resources of the cave, suggested hydraulic pressure as the causative agent (Pengelly, 1876; p.176). Sutcliffe (1960) ascribed the cracking at Joint Mitnor and Reed's Cave to a period of frost shattering that must have post-dated the Eemianaged (MIS 5e) bone deposit. Later still, during an extensive study of the Kents Cavern sediments, Proctor (1994) reverted to MacEnery's earthquake theory. Subsequently, using a single radiometric date from Proctor's unpublished study, Straw (1997) conjectured that the cracking must have been caused by a single strong earthquake between $\sim 100 \mathrm{ka}$ and 75 ka. In response to Straw's (1997) article, Ford (1997) collected together several references to fractures observed in other caves in Devon, and speculated that all of them are attributable to earthquake activity. His evidence was largely negative, arguing that permafrost is unlikely $100 \mathrm{~km}$ from the late Pleistocene glacial margin and in a region under maritime influence, and, assuming that frost heave requires the presence of permafrost, the only explanation left to him was earthquake damage.

Our detailed geochronological study of the Kents Cavern speleothem deposits (Lundberg \& McFarlane, 2007) presented evidence, from dating of pre-and postcrack flowstones, that the cracking in every case was coincidental with glacial periods, and that fracturing occurred during each cold episode since the first layer of calcite was deposited in MIS 11. The implausibility of an appeal to such conveniently-timed episodes of tectonic activity demands an alternative explanation. However, it remains to demonstrate, contra Ford (1997), that frost heaving is a viable mechanism for flowstone cracking under realistic conditions. Here we present a theoretical model that demonstrates that frost heaving is both a feasible and very probable process in shallow caves with appropriate airflow in cold or periglacial environments. We use Kents Cavern, Devon $\left(50.4^{\circ} \mathrm{N}, 3.5^{\circ} \mathrm{W}\right)$ as the type example.

\section{Geological and paleoenvironmental context}

Kents Cavern is developed in Middle-Upper Devonian Torquay Limestone, underlain by the Meadfoot Group of purple-grey mudstone (locally called Nordon Slates), and overlain by Upper Devonian Salton Cove Formation of purple and grey-green mudstones (locally called Gurrington Slate) (Durrance \& Laming, 1982; Scrivener, 1987). These rocks were uplifted, severely fractured and folded by the Variscan Orogeny (390-310 Ma) and then overlaid by New Red Sandstones of Permian age. Many relatively small caves have formed in the Torquay Limestone, probably mainly in the early Pleistocene, but speleogenesis may have involved some rejuvenation of the paleokarstic features. Kents Cavern is the third largest cave in the region with just under $1 \mathrm{~km}$ of mapped passages.

The cave has been largely inactive speleogenetically since the mid-Pleistocene and has been filled with sediments and speleothem. The sequence of sedimentary fill is, briefly, from oldest to youngest (Lundberg \& McFarlane, 2007):

(i) The Red Sands, a finely bedded deposit of red sands and clay, of Cromerian age;

(ii) The Breccia, a solifluction debris flow carried into the cave from now-blocked entrances during the intense Anglian (MIS 12) glacial episode - this is a poorly sorted and generally homogenous, matrixsupported diamict of angular-to-sub-angular clasts (up to $20 \mathrm{~cm}$ in size) in a matrix of red mud (Proctor, 1994);

(iii) The Crystalline Stalagmite, a complex assemblage of flowstones of variable thickness up to $1.5 \mathrm{~m}$ that overlies the Breccia, laid down during four successive interglacials, beginning with the Hoxnian (MIS 11) interglacial some 400,000 years ago; (iv) The Cave Earth, a mixture of mud, sand and rock fragments laid down from $\sim 24 \mathrm{ka}$ to $40 \mathrm{ka}$;

(v) The Granular Stalagmite, a thick deposit of vuggy flowstone that in places reaches 1.5 $\mathrm{m}$ thick, deposited from $\sim 11 \mathrm{ka}$ to $\sim 4 \mathrm{ka}$.

The cave displays many examples of flowstones that have cracked, shifted slightly and been filled and re-cemented (Fig. 2). In some cases, the same flowstone has been cracked and re-cemented more than once. In general the majority of the cracking is confined to the thinner layers - typically layers of less than $50 \mathrm{~cm}$; the thick bosses have remained intact.

This region of south Devon has never been directly impacted by the Pleistocene ice sheets but periglacial conditions were widespread during glacial periods (Cullingford, 1982). The two ice-sheets that came closest to Kents Cavern were the last, marine isotope stage (MIS) 2, the Devensian, peaking at $20 \mathrm{ka}$, and the MIS 12, the Anglian, at 430 ka (Fig. 1). Periglaciation triggered extensive frost action and produced thick periglacial slope deposits or solifluction deposits 

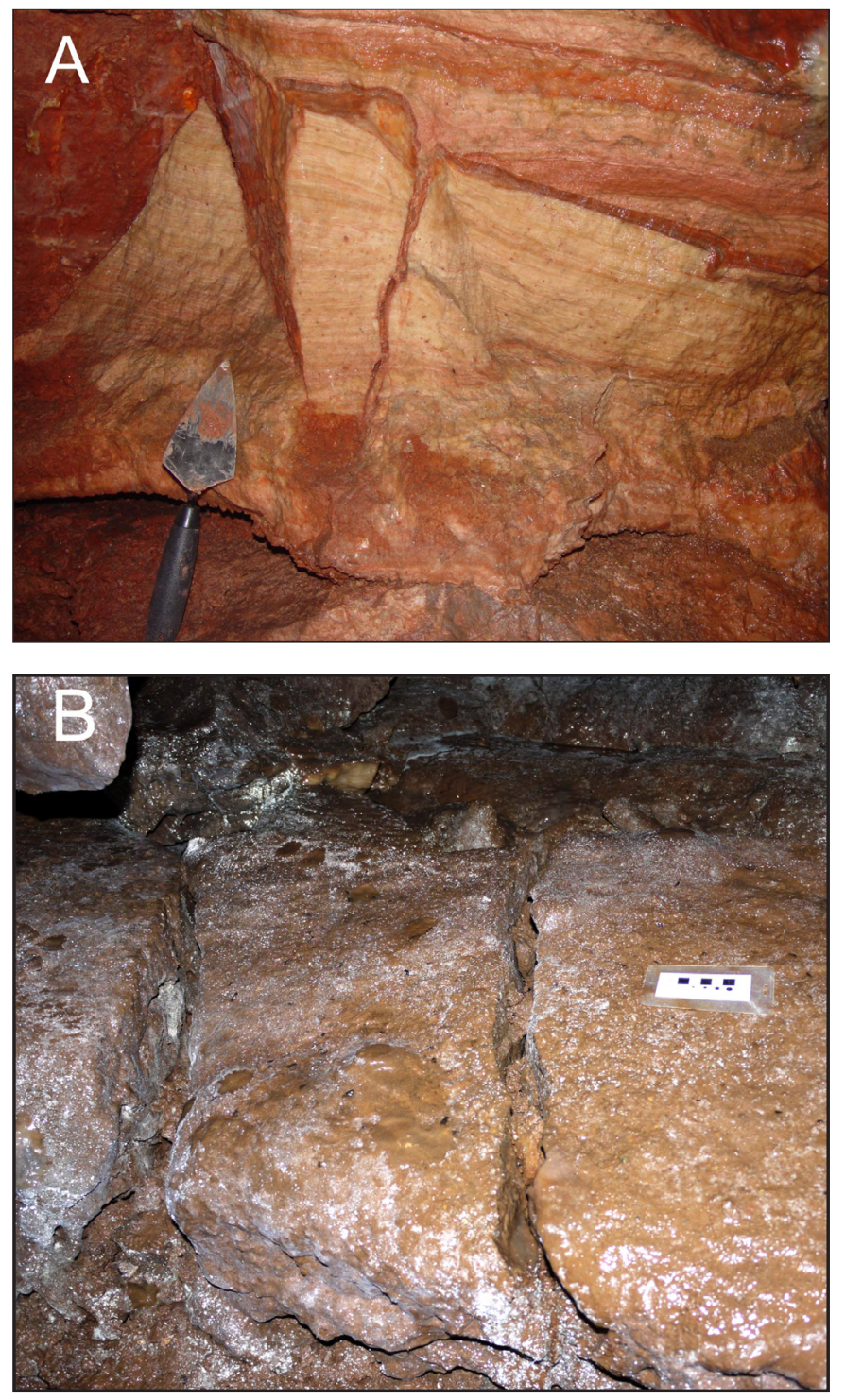

Fig. 2. a) Profile view of cracked flowstone from Kents Cavern. The base of the trowel rests on the breccia. The main body of flowstone has been dated to MIS 9 and the overlying redder, layers to MIS 7: the crack and the dark red calcite that fills it formed between 310 \pm 6 ka and $210 \pm 4$ ka (Lundberg \& McFarlane, 2007). b) Looking down on fractures in $\sim 10$-cm-thick flowstone of Joint Mitnor Cave (scale shows $1 \mathrm{~cm}$ bars).

(Cullingford, 1982). Ford's (1997) argument that the Kents Cavern region could not have been cold enough for frost action is largely contradicted by empirical evidence of fossil polygons and stripes within about $10 \mathrm{~km}$ of the cave and many examples of frost-related features both on Dartmoor and at many coastal sites all around Devon and Cornwall (Croot \& Griffiths, 2001). Ballantyne \& Harris's (1993) finding of a fossil pingo on West Dartmoor (average elevation $365 \mathrm{~m}$ asl; Griffiths 1996) suggests that Devon probably experienced discontinuous permafrost, at least during the coldest periods and at modest elevations. Croot $\&$ Griffiths (2001) suggest that during glacial periods the climate of Devon may have been similar to that of Svalbard today, a region of permanent ice inland and periglacial coastlands. The maritime influence on the Kents Cavern region was considerably reduced during glacial periods by coastal retreat to some 145 km distance (Cambridge University, 2009; Fig. 1).

\section{MODELING}

A realistic model of frost-heaving in caves requires (a) that winter airflow in periglacial environments is adequate to remove enough heat from the sediments to achieve freezing on sub-annual timescales; (b) that thermal diffusion is sufficient to freeze wet sediments below flowstone floors on appropriate timescales, and (c) that the expansion of freezing sediments is sufficient to fracture flowstone floors of up to $\sim 50 \mathrm{~cm}$ thickness.

\section{Heat flow estimate}

In order to estimate the amount of cooling that the cave sediments may experience in a reasonable time frame, we modeled the Bear's Den to South Entrance route in Kents Cavern (Fig. 3) as an open passage $100 \mathrm{~m}$ long, $6 \mathrm{~m}$ wide, and $4 \mathrm{~m}$ high, floored by an additional $2 \mathrm{~m}$ of breccia with a $30 \mathrm{~cm}$ thick flowstone capping (Fig. 4). The breccia has $\sim 30 \%$ porosity and is saturated. For the purposes of modeling, the $70 \%$ solid component of the matrix-supported breccia is assumed to be made up of $\sim 20 \%$ limestone-shale rock fragments and $\sim 50 \%$ mica-feldspar clay (Table $1)$. Thus the model is made up of five components: rock clasts, clay, and water in the breccia; calcite flowstone; and cave air. Values for material properties used below have been taken from Waples \& Waples (2004) and www.engineeringtoolbox.com.

Approximating the density of breccia clasts as $2.50 \mathrm{~g} . \mathrm{cm}^{-3}$, clay as $2.79 \mathrm{~g} . \mathrm{cm}^{-3}$ and calcite as 2.75 g. $\mathrm{cm}^{-3}$, the density of the wet sediment of $30 \%$ porosity is thus $\sim 2.20 \mathrm{~g} . \mathrm{cm}^{-3}$ and the total mass of sediment and flowstone is $3.13 \times 10^{6} \mathrm{~kg}$. Specific heat values for materials vary a little with conditions and temperature; most published data are for $20^{\circ} \mathrm{C}$. Using specific heat values (from www.engineeringtoolbox. com) for clasts of $0.91 \mathrm{KJ} / \mathrm{kg} / \mathrm{K}$, clay 0.92 , water 4.18 , and calcite 0.82 , the total heat capacity of the sediment fill of the $100 \mathrm{~m}$-long passage is thus $4.00 \mathrm{x}$ $10^{6} \mathrm{KJ} / \mathrm{K}$ (Table 1). If we use the slightly lower specific heat values given in Waples \& Waples (2004), then the total heat capacity is very slightly lower, at $3.88 \times 10^{6}$ $\mathrm{KJ} / \mathrm{K}$ (but this makes no significant difference to the end result).

The modern mean annual temperature of the Kents Cavern surface environment is $9.5 \pm 1.8^{\circ} \mathrm{C}$ (Grieser et al., 2006). The presence of periglacial features such as pingos on Dartmoor (Ballantyne \& Harris, 1993) suggests a mean annual temperature of -3 to $-1^{\circ} \mathrm{C}$ (Mackay 1988 ) within $20-30 \mathrm{~km}$ of the cave for at least some of the Devensian glacial period, but this evidence is not strong enough to allow a confident estimate of glacial mean annual temperatures for Kents Cavern itself. Various references (see review in Murton \& Lautridou, 2003) suggest a mean annual temperature below zero in this part of Britain for much of isotope stage 2. Conservatively, if we assume that the mean annual temperature was only about half the modern value, i.e. $\sim 5^{\circ} \mathrm{C}$, then the heat that must be removed from the sediment-plus-flowstone mass is $2.0 \times 10^{7} \mathrm{KJ}$. This addresses the sensible heat only, to bring the material to $0^{\circ} \mathrm{C}$. In order to freeze it, we must also include the much larger component the latent heat of fusion of water within the sediment $\left(1.2 \times 10^{8} \mathrm{KJ}\right)$. This raises the total energy that must 


\section{A. Plan of Kents Cavern, showing main breccia deposits}

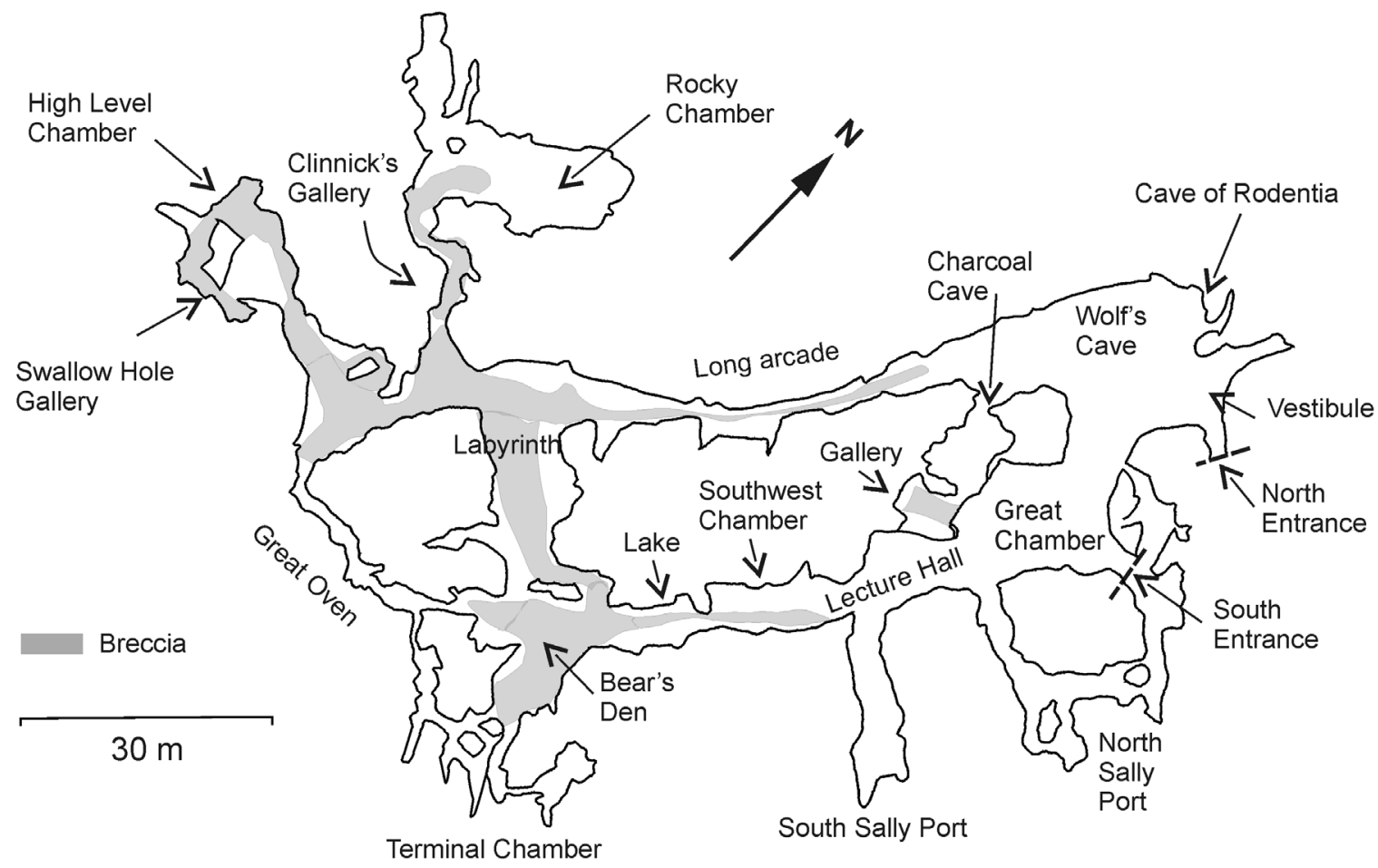

\section{B. Extended Long Section from Bear's Den to Lecture Hall to Wolf's Cave}

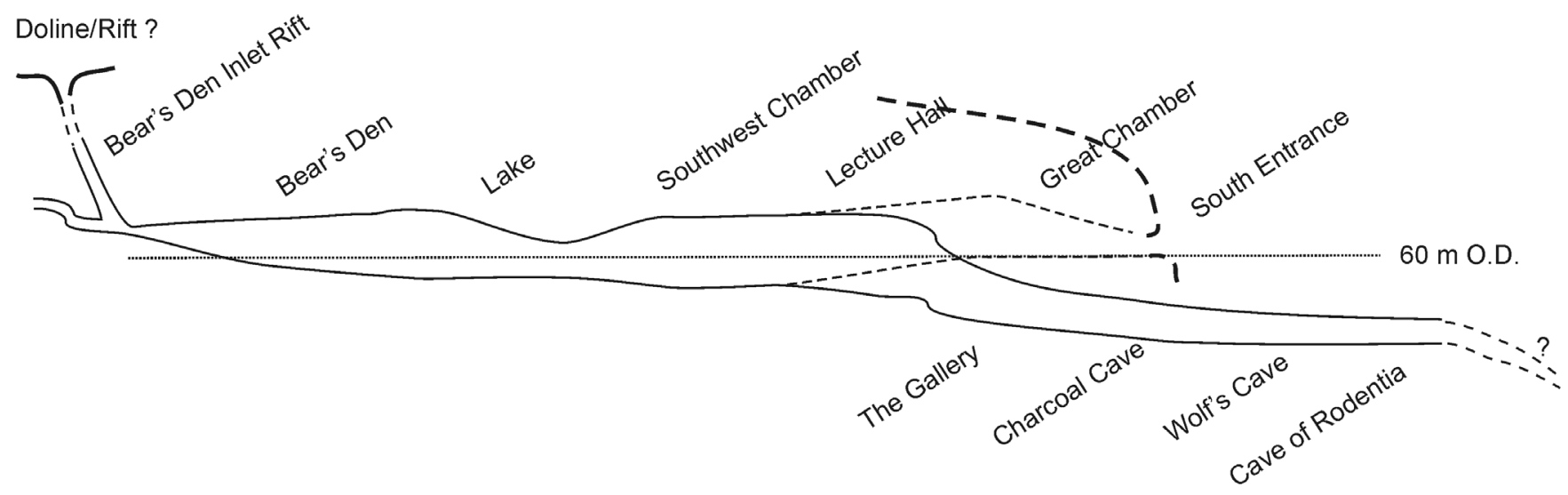

Fig. 3. a) Plan of Kents Cavern (modified from original survey by Proctor \& Smart, 1989) showing the main areas of breccia (pale grey shading). b) Extended long section showing the elevation change.

be removed from the sediment-plus-flowstone to $1.4 \mathrm{x}$ $10^{8} \mathrm{KJ}$ (Table 1$)$. This value is dominated by the latent heat and the value used for mean annual temperature has little effect: eg, using the modern value of $9.5^{\circ} \mathrm{C}$ raises it to only $1.6 \times 10^{8} \mathrm{KJ}$. Increasing the depth of saturated breccia increases the energy in a linear fashion by a factor of 0.7 , e.g., 3 m yields 2.1 x $10^{8} \mathrm{KJ}$.

\section{How can this heat transfer be effected?}

The configuration of Kents Cavern is such that air could flow freely between two entrances - an upper entrance at the back of the cave used by the bears and into which the periglacial mud flows entered (Lundberg \& McFarlane, 2007) and the slightly lower South Entrance or the distinctly lower Cave of Rodentia (Fig. 3B). In caves with such a configuration air flow depends on the differences in pressure between the two entrances: e.g., cold dense air may sink into the upper entrance and flow out of the lower entrance (Palmer, 2007, p.326-328).

If we assume that the winter air had a temperature of $-15^{\circ} \mathrm{C}$ (a value that is typical of Svalbard today: Norwegian Meteorological Institute website), and given that the heat capacity of dry air at $0^{\circ} \mathrm{C}$ is $\sim 1.3 \mathrm{KJ} / \mathrm{m}^{3} . \mathrm{K}$ 
Table 1. Calculations of heat removal requirements

\begin{tabular}{|c|c|c|c|c|}
\hline & CLAST & CLAY & WATER & CALCITE \\
\hline Volume $\left(\mathrm{m}^{3}\right)$ & 240 & 600 & 360 & 180 \\
\hline Density $\left(\mathrm{kg} / \mathrm{m}^{3}\right)$ & 2500 & 2790 & 1000 & 2750 \\
\hline Density breccia alone & 2.195 & & & \\
\hline Mass (kg) & $6.00 \mathrm{E}+05$ & 1.67E+06 & $3.60 \mathrm{E}+05$ & $4.95 E+05$ \\
\hline Total mass breccia & $2.63 \mathrm{E}+06$ & & & \\
\hline Total mass breccia + calcite $(\mathrm{kg})$ & $3.13 E+06$ & & & \\
\hline Specific heat $(\mathrm{KJ} / \mathrm{kg} / \mathrm{K})$ & 0.914 & 0.92 & 4.18 & 0.82 \\
\hline Heat capacity & $5.48 \mathrm{E}+05$ & $1.54 \mathrm{E}+06$ & $1.50 \mathrm{E}+06$ & 4.06E+05 \\
\hline Total heat capacity breccia + calcite $(\mathrm{KJ} / \mathrm{K})$ & $4.00 \mathrm{E}+06$ & & & \\
\hline Heat to be removed for $5 \mathrm{~K}$ temp drop & $2.74 \mathrm{E}+06$ & $7.70 E+06$ & $7.52 E+06$ & $2.03 E+06$ \\
\hline Latent heat of fusion of water mass $(\mathrm{KJ})$ & $1.20 \mathrm{E}+08$ & & & \\
\hline Total heat to be removed $(\mathrm{KJ})$ & $1.40 \mathrm{E}+08$ & & & \\
\hline
\end{tabular}

(using specific heat capacity of $1.005 \mathrm{KJ} / \mathrm{kg} / \mathrm{K}$ and density of $1.293 \mathrm{~kg} / \mathrm{m}^{3}$ at $20^{\circ} \mathrm{C}$ at sea level: http:// www.engineeringtoolbox.com), then a minimum of $7.21 \times 10^{6} \mathrm{~m}^{3}$ of air must move through the cave in order to remove the $1.40 \times 10^{8} \mathrm{KJ}$ of heat. Given a modeled passage volume of $2400 \mathrm{~m}^{3}$ this would require an air flow velocity of 30 changes per day which is 125 $\mathrm{m} \mathrm{hr} \mathrm{h}^{-1}$ or $0.035 \mathrm{~m} \mathrm{~s}^{-1}$ (Table 2A). These are quite low air flow rates: De Freitas et al. (1982), for one example in a temperate zone cave, measured mean winter flow rates of $0.37 \mathrm{~m} \mathrm{~s}^{-1}$, an order of magnitude higher than required by our model. In another example, Pflitsch \& Piasecki (2003) measured air flows of $0.15 \mathrm{~m} \mathrm{~s}^{-1}$ in part of a two-entrance Polish cave. Thus the model suggests that air flow in Kents Cavern would have been more than adequate to remove the necessary heat. If we raise the depth of breccia to $4 \mathrm{~m}$, then the air flow required is still only $0.07 \mathrm{~m} \mathrm{~s}^{-1}$ (Table 2B).

At Joint Mitnor Cave, which probably had only a single opening in the Pleistocene, the mechanism would have been cold-air "ponding" at the base of the shaft, a phenomenon that is well known and which

Table 2. Air flow requirements

\begin{tabular}{lrl}
\hline \multicolumn{3}{c}{ A. Air flow calculations } \\
\hline Winter air temp below $0^{\circ} \mathrm{C}$ & 15 & $\mathrm{C}$ \\
Heat capacity of air & 1.297 & $\mathrm{KJ} / \mathrm{m}^{3} . \mathrm{K}$ \\
Heat to be removed & $1.40 \mathrm{E}+08$ & $\mathrm{KJ}$ \\
Cave air volume & 2400 & $\mathrm{~m}^{3}$ \\
Number of days & 100 & \\
Length of passage & 100 & $\mathrm{~m}$ \\
Volume air required & $7.21 \mathrm{E}+06$ & $\mathrm{~m}^{3}$ \\
Number of exchanges & 3003 & \\
Exchanges per day & 30 & \\
Flow per day & 3003 & $\mathrm{~m} / 24 \mathrm{hrs}$ \\
Flow per second & 0.035 & $\mathrm{~m} / \mathrm{sec}$
\end{tabular}

accumulates permanent ice in caves even under today's much milder climatic regimes (e.g., Scărişoara Cave, Romania, elevation 1165 m; Perşoiu, 2004).

\section{Depth of freezing estimate}

Having demonstrated that winter periglacial airflow is more than sufficient to achieve sediment freezing, it is next necessary to show that the appropriate exchange of heat can occur in the available time frame. The mechanism of heat transfer in sediment (i.e., the propagation of a surface temperature wave into sediment) relates to the thermal properties of the materials. The Stefan solution is used to estimate depth of freezing over time of a material that is at $0^{\circ} \mathrm{C}$ (Mackay, 1987).

The thermal conductivity of composite ground material (i.e., the breccia with $30 \%$ water, $50 \%$ micafeldspar clay, 20\% limestone-shale clasts) can be estimated following Burn (2004):

$$
\lambda_{b}=\lambda_{w}^{p} \cdot \lambda_{m}^{(1-p)}
$$

where $\lambda_{b}=$ thermal conductivity of breccia, $\lambda_{\mathrm{w}}=$ thermal conductivity of water, $p=$ porosity, and $\lambda_{\mathrm{m}}=$ thermal conductivity of the mineral component (Table 3A). For saturated material, the thermal conductivity of air is not required. Depth of frost penetration is directly related to thermal conductivity, which increases on freezing. Values for thermal conductivity of soil materials are taken from Burn (2004) yielding thermal conductivities for the unfrozen and frozen breccia of 1.21 and $1.83 \mathrm{~W} / \mathrm{m} / \mathrm{C}$, respectively. If, instead, we use the slightly different values for thermal conductivity of the component materials given in http://pubs.nrc-cnrc.gc.ca/rp/rppdf/t04081.pdf, then the values are 1.08 and $1.61 \mathrm{~W} / \mathrm{m} / \mathrm{C}$, but the final result is insensitive to these differences.

B. Heat removal required for different depths of sediment

\begin{tabular}{lccccc}
\hline Breccia depth & $\mathrm{m}$ & 1 & 2 & 3 & 4 \\
Heat to be removed & $\mathrm{KJ}$ & $7.11 \mathrm{E}+07$ & $1.40 \mathrm{E}+08$ & $2.09 \mathrm{E}+08$ & $2.78 \mathrm{E}+08$ \\
Flow required & $\mathrm{m} / \mathrm{sec}$ & 0.018 & 0.035 & 0.052 & 0.069 \\
\hline
\end{tabular}




\section{$6 \times 4 \mathrm{~m}$ open passage}

\section{$0.3 \mathrm{~m}$ of flowstone}

$2 \mathrm{~m}$ of saturated matrix-supported breccia

Fig. 4. Simple model of passage used in estimations. The flowstone is fixed to the walls creating a sealed chamber of saturated breccia.

The Stefan solution is then used to estimate depth of freezing for different conditions:

$$
D=\sqrt{\frac{(2 \lambda T t)}{L}}
$$

where $D=$ depth of freezing in metres, $\lambda=$ thermal conductivity in $\mathrm{W} / \mathrm{m} / \mathrm{C}, T=$ temperature below $0^{\circ} \mathrm{C}$, $t=$ time in seconds, and $L=$ (latent heat of fusion of water $\mathrm{x}$ porosity). The result for 100 days at $-15^{\circ} \mathrm{C}$ is freezing to a depth of $2.18 \mathrm{~m}$ using the first set of values for thermal conductivity (Table 3B), or 2.05 $\mathrm{m}$ using the second set of values. Thus a single 14 week season of $-15^{\circ} \mathrm{C}$ temperatures is sufficient to freeze $\geq 2 \mathrm{~m}$ thickness of breccia. Alternatively, a single 18 week season at $-10^{\circ} \mathrm{C}$ would achieve the

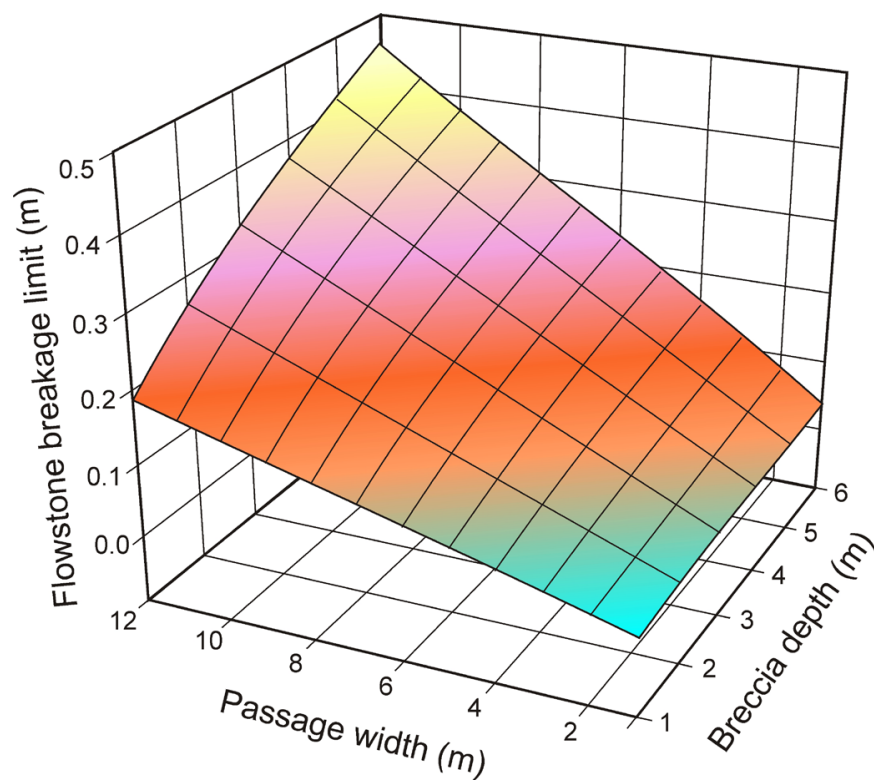

Fig. 5. Graph of maximum flowstone breakage thickness varying with depth of frozen sediment and passage width. same result. Propagation of the freezing front through the capping calcite is very fast since porosity is low and thermal conductivity high $(4.6 \mathrm{~W} / \mathrm{m} / \mathrm{C}$ : http:// www.almazoptics.com/CaCO3.htm): at $-15^{\circ} \mathrm{C}$ freezing would penetrate $30 \mathrm{~cm}$ of calcite in about 3 hours. Varying the proportions of the different components makes little difference to the result: e.g., reducing the proportion of clay makes virtually no difference. Reducing the water content increases the rate of freezing: e.g., at $20 \%$ porosity the breccia will be frozen in 11 weeks rather than 14 weeks. These rates are consistent with values given in Mackay (1987) for growth of permafrost under newly drained lakes in the Canadian Arctic.

A simple estimate of expansion can be made for a passage that is $6 \mathrm{~m}$ wide and has $2 \mathrm{~m}$ of breccia at $30 \%$ porosity. The $3.6 \mathrm{~m}^{2}$ of water $\left(30 \%\right.$ of $\left.12 \mathrm{~m}^{2}\right)$, at $9 \%$ expansion, becomes $3.9 \mathrm{~m}^{2}$ of ice (ie, $12.3 \mathrm{~m}^{2}$ of breccia). The resultant heave of the breccia surface, confined on all sides except the top, is $5.4 \mathrm{~cm}$ if applied evenly over the whole surface, and obviously more if focused towards the centre, a situation that is likely in field conditions as a result of freezing from the bottom and sides. During freezing, pore water expulsion from the sides and bottom as well as the top is likely to concentrate the water, and thus focus the expansion, towards the centre of the passage.

This demonstrates that complete freezing of the breccia could easily have been achieved in a single cold season (it only needs to happen once) and that the resultant heave would have been significant. Obviously, the depth of saturated sediment that can be frozen in a single season reaches some limit: for our modeled passage $1 \mathrm{~m}$ of breccia will freeze in 3 weeks of $-15^{\circ} \mathrm{C}$ air flow, $2 \mathrm{~m}$ in 12 weeks and $3 \mathrm{~m}$ in 30 weeks (Table 3C). This is probably the limit for seasonal freezing in this climatic regime.

\section{Calculations of critical thickness of flowstone span}

Having established that the Kents Cavern sediments would be expected to have frozen each periglacial winter season, and would have responded with a substantial vertical displacement in an unconfined setting, we next demonstrate that, when confined by a flowstone capping, the expansive force of the freezing sediments is sufficient to break the flowstone.

The forces exerted by freezing cave sediments under a calcite layer fixed to the walls approximate the dynamics of closed-system pingo formation by freezing under ice-bonded permafrost, as modeled by Mackay (1987). As freezing progresses downwards under the ice-bonded surface (or, here, under the calcite-bonded surface), pressures increase in the remaining pore waters beneath the frozen fringe, proportional to the bulk unit weight of the frozen sediment and the depth of freezing. The bulk unit weight of frozen sediment (estimated from typical proportions of clasts/clay/ water/ice in the breccia: Table 4) is $2195 \mathrm{~kg} / \mathrm{m}^{3}$ or $21.5 \mathrm{kN} / \mathrm{m}^{3}$. Pore water pressure can be estimated using formula [7] from Mackay (1987):

$$
P=0.75 w . D
$$

where $P$ is the pore water pressure, $w$ is the bulk unit weight of the frozen sediment in $\mathrm{kN} / \mathrm{m}^{3}$, and $D$ 
Table 3. Estimation of the depth of freezing of breccia using the Stefan Solution (Burn, 2004). Values for thermal conductivity taken from Burn, 2004

\begin{tabular}{lcccccccc}
\hline \multicolumn{7}{c}{ A. Calculations of thermal conductivity of breccia } \\
\hline & Limestone & Shale & Mica & Feldspar & Water & Ice & Unfrozen Breccia & Frozen Breccia \\
$\begin{array}{l}\text { Proportion } \\
\begin{array}{l}\text { Thermal } \\
\text { conductivity }(\lambda)\end{array}\end{array}$ & 0.1 & 0.1 & 0.25 & 0.25 & 0.3 or 0 & 0 or 0.30 & & \\
W/m/C & 2.9 & 1.5 & 3.0 & 2.0 & 0.56 & 2.2 & 1.21 & 1.83 \\
\hline
\end{tabular}

\begin{tabular}{|c|c|c|c|c|c|c|}
\hline \multicolumn{7}{|c|}{ B. Parameters used in Stefan solution } \\
\hline \multicolumn{4}{|c|}{ Latent heat of fusion of water $\mathrm{J} / \mathrm{m}^{3}$} & \multicolumn{3}{|c|}{$3.33 \times 10^{8}$} \\
\hline \multicolumn{4}{|l|}{ Porosity } & \multicolumn{3}{|c|}{0.30} \\
\hline \multicolumn{4}{|l|}{ Latent heat $\mathrm{x}$ porosity } & \multicolumn{3}{|c|}{$9.99 \times 10^{7}$} \\
\hline \multicolumn{4}{|l|}{ Temp below zero $\mathrm{K}$} & \multicolumn{3}{|c|}{15} \\
\hline \multicolumn{4}{|l|}{ Time (seconds) } & \multicolumn{3}{|c|}{8640000} \\
\hline \multicolumn{4}{|l|}{ Time (days) } & \multicolumn{3}{|c|}{100} \\
\hline Stefan solution for: & \multicolumn{3}{|c|}{ Unfrozen Breccia } & \multicolumn{3}{|c|}{ Frozen Breccia } \\
\hline Depth of freezing $(\mathrm{m})$ & \multicolumn{3}{|c|}{1.77} & \multicolumn{3}{|c|}{2.18} \\
\hline \multicolumn{7}{|c|}{$\begin{array}{l}\text { C. Time required for freezing to different depths } \\
\text { at }-15^{\circ} \mathrm{C} \text { air temperature }\end{array}$} \\
\hline Depth of freezing $(\mathrm{m})$ & 1 & 2 & 3 & 4 & 5 & 6 \\
\hline Days required & 20 & 85 & 210 & 360 & 550 & 800 \\
\hline
\end{tabular}

is the depth of the frozen sediment in $\mathrm{m}$. Pore water pressure at the base of the $2 \mathrm{~m}$-thick freezing breccia is estimated at $32 \mathrm{kN} / \mathrm{m}^{2}$ or $0.032 \mathrm{MPa}$, rising to 0.097 MPa for a 6-m thick fill (Table 4).

Rising sub-calcite pressure eventually causes deflection and failure, the maximum deflection occurring at the centre of the flowstone which is clamped at both sides to the passage wall. The onset of failure, driven by the pore pressure, depends on the flexural strength of the material. Values for flexural strength of flowstone are rare in the literature. Cadorin et al. (2001) report tensile strengths of $1.94 \pm 0.7 \mathrm{MPa}$ for four broken stalagmites from a Belgian Cave; Lacave et al. (2004) report a non-normal distribution of tensile strengths for 20 stalactites with a median of $3.75 \mathrm{MPa}$ and a range up to $7.7 \mathrm{MPa}$. However, flowstones are structurally quite different from stalagmites. Thus, for the purposes of this modeling, the flexural strength of several flowstones was determined in the laboratory. Conservation ethics precluded sampling of the little remaining flowstone in Kents Cavern. Instead samples were recovered from pre-existing excavations in three caves/quarries of the nearby Mendip Hills, England, and sawn into rectangular bars of varying dimensions but approximately square cross-section. Samples were broken by application of a known steady force in a simple lever arrangement, as per Lacave et al. (2004). Flexural strength, the strength under normal stress, was determined as force at point of breakage divided by cross-sectional area at the point of fracture. Natural flowstone has great natural variability, resulting in high standard deviations. Our result, $11.1 \pm 5.8 \mathrm{MPa}$ ( $n$ $=7$ ), is quite similar to published values for cements, marbles, and many rocks. Marini \& Bellopede (2007) measured 12.5 MPa for marble slabs (Venato marble, from the Carrara quarry). Waltham (2009, p. 52) gives typical tensile strength values for various geological materials including granite at $15 \mathrm{MPa}$, basalt at 15 $\mathrm{MPa}$, sandstone greywacke at $15 \mathrm{MPa}$, Carboniferous limestone at $10 \mathrm{MPa}$, and marble, gneiss and slate all at $10 \mathrm{MPa}$.

The value for flexural strength of the material can be applied to formula [16] of Mackay (1987):

$$
q=1.5 F S \frac{T h^{2}}{R^{2}}
$$

where $q$ is the driving pressure at failure, Th is the thickness of flowstone in metres, $R$ is the passage radius, and FS is the flexural strength of flowstone. This then allows us to derive the maximum thickness of material that will fail for different passage sizes and thicknesses of overburden. For the modeled passage $6 \mathrm{~m}$ wide and $2 \mathrm{~m}$ of freezing breccia, the resultant pore pressure is sufficient to fracture $0.13 \pm 0.04 \mathrm{~m}$ of calcite (assuming no flaws - a situation rare in nature - so this thickness is probably conservative).

Pore water pressures change only a little with thickness of frozen sediments at realistic cave scales - the breccia is unlikely to be much thicker than $6 \mathrm{~m}$, which yields a pore pressure of $0.097 \mathrm{MPa}$. This will break $0.23 \pm 0.07 \mathrm{~m}$ of calcite. The model is obviously somewhat sensitive to the flexural strength: for example, $5 \mathrm{MPa}$ yields a $0.19 \mathrm{~m}$ break, but $20 \mathrm{MPa}$ only $0.10 \mathrm{~m}$. The parameter with the greatest impact is passage width: for example, if the thickness of breccia remains at $2 \mathrm{~m}$ but the passage width increases to 12 $\mathrm{m}$, the flowstone breaking thickness increases to 0.26 $\pm 0.08 \mathrm{~m}$ (Table 4B). Fig. 5 shows the model results of maximum flowstone breakage thickness against changing breccia depth, and changing passage width.

This model suggests that it would be quite feasible for freezing of a 2-m-thick under-layer of saturated sediment in a modest 6-m-wide passage to cause shattering of a flowstone layer $\sim 13 \mathrm{~cm}$ thick, rising to $\sim 26 \mathrm{~cm}$ in a $12-\mathrm{m}$-wide passage. These numbers are based on flexural strengths measured on flawfree samples of flowstone - in the field, the presence of natural flaws would increase the thickness that could be shattered. The model is not intended to be exhaustively rigorous; rather, it has been put forward to support the argument that shattered flowstone must not always be interpreted as indicative of former earthquakes, that freezing is a viable mechanism to explain shattering of flowstone in those areas that are not normally tectonically active but experienced cold conditions in the past. 


\section{DISCUSSION}

Several arguments against the earthquake theory of fractured flowstone can be mounted, on morphological grounds and on statistical improbability grounds.

Broken speleothems are commonly reported in the literature but surprisingly few can be clearly attributed to earthquake damage. Gilli (2005) reviews some of the causes, such as movements of sediments in caves. Examples from continental Europe of broken and toppled stalactites and stalagmites caused by mass movement of glacial cave ice are described by Kempe et al. (2009). Forti (2001) and Panno et al. (2009) report that earthquake impacts are expressed in speleothems most commonly not as a fracture but rather as a shift in the angle of growth or a shift in the rate of growth. In many cases the earthquake alters the patterns of subsequent water dripping but does not have any immediate impact on the formations. Lacave et al. (2004), Gilli (2005), and Becker et al. (2006) all remark on the surprisingly minor impact of earthquakes in caves. Straw stalactites are readily broken but only exceptionally long and thin stalagmites or stalactites are affected. The fractures in Kents Cavern are generally not of pendant or upright forms. The fact that earthquakes rarely cause breakage even in regions that are much more prone to tremors than England, and that this is always of pendant or upright forms - breakage of flowstone from earthquake damage has never been reported - suggests that it is most unlikely that the Kents flowstone fractures are from earthquake damage.
The extreme improbability of earthquakes being repeatedly and exclusively coincident with glacial episodes impacting south Devon caves leaves Sutcliffe's (1960) frost-heave hypothesis as the only currently viable alternative. The counterargument that the region could not have been cold enough is inconsistent with current understanding of Pleistocene glacial environments. Moreover, frostheave certainly does not require the presence of permafrost, either continuous or discontinuous, and it only requires one significant frost-heave event per cold interval to fracture the flowstone floors in Kents Cavern. Thus we argue that the evidence for frost heaving is overwhelming.

The modelling above shows that frost heave of a moderately thick water-saturated sediment could effectively crack a relatively substantial layer of calcite. The calculated critical thickness of $\sim 13-26$ $\mathrm{cm}$ is supported by field evidence from Kents Cavern that flowstone or bosses thicker than $\sim 30 \mathrm{~cm}$ do not fracture. In addition mapping of the broken flowstone in relation to breccia thickness demonstrated that the fracture is associated largely with the thickest breccia (Lundberg \& McFarlane, 2007). Fracture is likely to be greatest in the centres of passages, both because pore-water expulsion is likely to focus the highest pressures here, and because flowstone commonly is thickest close to walls or bosses, and thinnest at the centre.

This model requires three conditions: suitable climatic conditions, suitable passage geometry, and suitable sedimentary sequence. Suitably cold

Table 4. Calculations of thickness of flowstone breakage.

\begin{tabular}{lr}
\hline A. Application of Mackay (1987) formulae & \\
\hline Bulk unit weight of frozen sediment & $21.53 \mathrm{kN} / \mathrm{m}^{3}$ \\
Thickness of frozen material & $2 \mathrm{~m}$ \\
Pore-water pressure, using Mackay 1987, formula [7] & $0.0322 \mathrm{MPa}$ \\
Radius of passage & $3 \mathrm{~m}$ \\
Flexural strength from lab tests & $11.1 \pm 5.8 \mathrm{MPa}$ \\
Thickness of calcite that can be broken for this pore pressure, using Mackay 1987, formula [16] & $0.13 \pm 0.04 \mathrm{~m}$ \\
\hline
\end{tabular}

B. Summary of thickness of flowstone breakage (in metres) varying with breccia depth and passage width

\begin{tabular}{c|cccccc}
\hline \multicolumn{7}{c}{ Breccia depth $(\mathbf{m})$} \\
\hline Passage width $(\mathbf{m})$ & 1 & 2 & 3 & 4 & 5 & 6 \\
\cline { 2 - 6 } $\mathbf{1}$ & 0.02 & 0.02 & 0.03 & 0.03 & 0.03 & 0.04 \\
$\mathbf{2}$ & 0.03 & 0.04 & 0.05 & 0.06 & 0.07 & 0.08 \\
$\mathbf{3}$ & 0.05 & 0.07 & 0.08 & 0.09 & 0.10 & 0.11 \\
$\mathbf{4}$ & 0.06 & 0.09 & 0.11 & 0.12 & 0.14 & 0.15 \\
$\mathbf{5}$ & 0.08 & 0.11 & 0.13 & 0.16 & 0.17 & 0.19 \\
$\mathbf{6}$ & 0.09 & 0.13 & 0.16 & 0.19 & 0.21 & 0.23 \\
$\mathbf{7}$ & 0.11 & 0.15 & 0.19 & 0.22 & 0.24 & 0.27 \\
$\mathbf{8}$ & 0.12 & 0.18 & 0.22 & 0.25 & 0.28 & 0.31 \\
$\mathbf{9}$ & 0.14 & 0.20 & 0.24 & 0.28 & 0.31 & 0.34 \\
$\mathbf{1 0}$ & 0.16 & 0.22 & 0.27 & 0.31 & 0.35 & 0.38 \\
$\mathbf{1 1}$ & 0.17 & 0.24 & 0.30 & 0.34 & 0.38 & 0.42 \\
$\mathbf{1 2}$ & 0.19 & 0.26 & 0.32 & 0.37 & 0.42 & 0.46 \\
\hline
\end{tabular}


climatic conditions would have been relatively common throughout the Pleistocene outside the zones of direct glacial cover but close enough to the ice for periglacial conditions. However, the cave must have a mechanism for cold air to enter and either pool, or flow through and out another entrance. These conditions would not be common. In Britain, even those caves that were not over-run by ice are likely to have had entrances plugged by mass movement or periglacial debris, eliminating air flow. Finally for frost heave to have any impact, flowstone must overlie water-rich sediment rather than rock.

Because of these limiting requirements, the majority of the caves in England, although they may have experienced periglacial conditions, do not show this kind of flowstone shattering. Kirkdale Cave, a famous Last Interglacial palaeontological site in Yorkshire (McFarlane \& Ford, 1998), is an example of a cave with a suitable sedimentary sequence but no fractures. This cave was over-run by ice at the glacial maximum, but would have been under periglacial conditions for long periods. When the eighteenth century excavators found the cave, a continuous and unfractured flowstone floor overlay a bone-bearing sandy mud deposit. This cave, which was found only when intersected by quarrying, is a low tunnel going into the hillside with a single blocked entrance, a morphology that does not admit cold air.

\section{CONCLUSION}

The extensive fracturing of flowstone that can be seen in several caves of Devon, England, is here shown to be most likely caused by cryogenic processes. Theoretical modeling based on parameters for a main passage in Kents Cavern, Devon, shows that 1 to 6 months of -10 to $-15^{\circ}$ $\mathrm{C}$ air flow at very modest velocities will result in freezing of 1 to $3 \mathrm{~m}$ of saturated sediment fill and achieve a $\sim 6 \mathrm{~cm}$ displacement, the extent of heave increasing with passage width and depth of frozen sediments. Where confined by flowstone attached to both passage walls, frost heave of the underlying sediment will fracture the flowstone. In the most conservative estimate, freezing of $2 \mathrm{~m}$ of sediments in a 6-m wide passage could fracture flowstone floors up to $\sim 13 \mathrm{~cm}$ thick, rising to $\sim 26 \mathrm{~cm}$ in a $12-\mathrm{m}$ wide passage - numbers that are quite consistent with the field evidence. Consideration of natural flaws in the flowstone raises the thickness that could be shattered. We conclude that frost-heaving and fracture of flowstone floors that overlie wet sediments is both a feasible and likely consequence of unidirectional air flow or cold-air ponding in caves and that this is the most likely mechanism for cracking in caves located in Pleistocene periglacial environments, and not known for tectonic activity. We suggest that most of the conjectural explanations in the literature (which have included earthquake damage, local shock damage from collapsing cave passages, and hydraulic pressure) are very unlikely to be the cause.

\section{ACKNOWLEDGEMENTS}

Many thanks to Chris Burn and Rane Curl for helpful discussions; to Nick Powe for generous hospitality and permission to work in Kents Cavern; to Nigel Taylor for providing flowstone specimens from Mendip excavations; to Pengelly Trust for access to Joint Mitnor Cave and to Peter Glanville for photos.

\section{REFERENCES}

Ballantyne C.K. \& Harris C., 1993 - The Periglaciation of Great Britain. Cambridge, Cambridge University Press, $330 \mathrm{p}$.

Becker A., Davenport C.A., Eichenberger U., Gilli E., Jeannin P.-Y. \& Lacave C., 2006 - Speleoseismology: A critical perspective. Journal of Seismology, 10: 371388. http://dx.doi.org/10.1007/s10950-006-9017-Z

Burn C.R., 2004 - The Thermal Regime of Cryosols. In: Kimble J.M. (Ed)., Cryosols. Berlin: SpringerVerlag: 391-413.

Cadorin J.F., Jongmans D., Plumier A., Camelbeeck T. Delaby S. \& Quinif Y., 2001 - Modelling of speleothems failure in Hotton cave (Belgium). Is the failure earthquake induced? Netherlands Journal of Geosciences, 80 (3-4): 315-321.

Cambridge University, 2009 - http:/www.qpg.geog.cam. ac.uk/research/projects/englishchannelformation/

Croot D. \& Griffiths J.S., 2001 - Engineering geological significance of relict periglacial activity in South and East Devon. Quarterly Journal of Engineering Geology and Hydrology, 34: 269-281. http://dx.doi.org/10.1144/qjegh.34.3.269

Cullingford R.A., 1982, The Quaternary. In: Durrance E.M. \& Laming D.J.C. (Eds)., The Geology of Devon: Exeter. University of Exeter Press: 249-290.

De Freitas C.R., Littlejohn R.N., Clarkson T.S. \& Kristament I.S., 1982 - Cave climate: Assessment of airflow and ventilation. International Journal of Climatology, 2 (4): 383-397. http://dx.doi.org/10.1002/joc.3370020408

Durrance E.M. \& Laming D.J.C. (Eds)., 1982 - The Geology of Devon. University of Exeter Press, Exeter, $346 \mathrm{p}$.

Ford T.D., 1997 - Stalagmite sheets shattered by earthquakes. Cave and Karst Science, 24: 140-141.

Forti P., 2001 - Seismotectonic and paleoseismic studies from speleothems: the state of the art. Geologica Belgica (vol. Karst \& Tectonics), 4/3-4: 175-185.

Gilli E., 2005 - Review on the use of natural cave speleothems as palaeoseismic or neotectonics indicators. Comptes Rendus Geoscience, 337: 1208-1215. http://dx.doi.org/10.1016/j.crte.2005.05.008

Grieser J., Gommes R., Cofield S. \& Bernardi M., 2006 - World maps of climatological net primary production of biomass, NPP. The Agromet Group, SDRN FAO of the UN, Viale delle Terme di Caracalla, 00100 Rome, Italy. http://www.fao.org/nr/ climpag/globgrids/NPP_en.asp.

Griffiths D., 1996 - The conservation and management of the industrial landscape within Dartmoor National Park. Mining History. Bulletin of the Peak District Mines Historical Society, 13 (2): 100-103. 
Kempe S., Bauer I. \& Dirks H., 2009 - Glacial cave ice as the cause of widespread destruction of interglacial and interstadial speleothem generations in central Europe. Proceedings of the $15^{\text {th }}$ International Congress of Speleology, 2: 1026-1031.

Lacave C., Koller M.G. \& Egozcue J.J, .2004 - 'What can be concluded about seismic history from broken and unbroken speleothems? Journal of Earthquake Engineering, 8 (3): 431-455.

http://dx.doi.org/10.1142/S1363246904001493

Lundberg J. \& McFarlane D.A., 2007 - Pleistocene depositional history in a periglacial terrane: A 500ka record from Kents Cavern, Devon, United Kingdom. Geosphere, 3: 199-219. http://dx.doi.org/10.1130/GES00085.1

MacEnery J., 1859 - Cavern researches, or, Discoveries of organic remains, and of British and Roman reliques, in the caves of Kent's Hole, Anstis Cove, Chudleigh, and Berry Head. Simpkin, Marshall, and Co., London, 78 p.

Mackay J.R., 1987 - Some mechanical aspects of pingo growth and failure, western Arctic coast, Canada. Canadian Journal of Earth Sciences, 24: 11081119. http://dx.doi.org/10.1139/e87-108

Mackay J.R., 1988 - Pingo collapse and paleoclimatic reconstruction. Canadian Journal of Earth Sciences, 25: 495-511. http://dx.doi.org/10.1139/e88-050

Marini P. \& Bellopede, R., 2007 - The influence of the climatic factors on the decay of marbles: an experimental study. American Journal of Environmental Sciences, 3 (3): 143-150.

McFarlane D.A. \& Ford D.C., 1998 - The age of the Kirkdale Cave palaeofauna. Cave and Karst Science, 25 (1): 3-6.

Murton J. B. \& Lautridou J-P., 2003 - Recent advances in the understanding of Quaternary periglacial features of the English Channel coastlands. Journal of Quaternary Science, 18: 301-307. http://dx.doi.org/10.1002/jqs.748

Norwegian Meteorological Institute. "Temperaturnormaler for Spitsbergen i perioden 1961 - 1990" http://retro.met.no/observasjoner/svalbard/ normaler for kommune 2111.html?kommuner. Retrieved 24 January 2012.

Palmer A.N., 2007 - Cave Geology. Cave Books, Dayton, Ohio, $454 \mathrm{p}$.

Panno S.V., Lundstrom C.C., Hackley K. C., Curry B.B., Fouke B.W. \& Zhang Z., 2009 - Major earthquakes recorded by speleothems in Midwestern U.S. caves. Bulletin of the Seismological Society of America, 99 (4): 2147-2154. http://dx.doi.org/10.1785/0120080261
Pengelly W., 1876 - Notes on recent notices of the geology and palaeontology of Devonshire (Part III). Reports and Transactions of the Devonshire Association, VIII: 148-244.

Pengelly W., 1869 - The literature of Kent's Cavern, Part II. Transactions of the Devonshire Association, 3: 191-482.

Pengelly W., 1884 - The literature of Kent's Cavern, part $V$. Transactions of the Devonshire Association, 14: 189-343.

Perşoiu A., 2004 - Ice speleothems in Scărişoara Cave: dynamics and controllers. Theoretical and Applied Karstology, 17: 71-76.

Pflitsch A. \& Piasecki J., 2003 - Detection of an airflow system in Niedzwiedzia (Bear) Cave, Kletno, Poland. Journal of Cave and Karst Studies, 65 (3): 160-173.

Proctor C.J. \& Smart P.L., 1989 - A new survey of Kent's Cavern, Devon. Proceedings - University of Bristol Spelaeological Society, 18 (3): 422429.

Proctor C.J., 1994 - A British Pleistocene chronology based on U-series and ESR dating of speleothem. Ph.D. thesis, University of Bristol, Bristol, 353 p.

Scrivener M.F., 1987 - An Introduction to the Geology of the Torquay District. Torquay Natural History Society, Torquay, $18 \mathrm{p}$.

Straw A., 1997 - Kent's Cavern - whence and whither? Cave and Karst Science, 24: 35-40.

Sutcliffe A. J. \& Zeuner F.E., 1962 - Excavations in the Torbryan Caves, Devonshire. 1. Tornewton Cave. Proceedings of the Devon Archaeological Exploration Society, 5: 127-145.

Sutcliffe A.J., 1960 - Joint Mitnor Cave, Buckfastleigh. Transactions of the Torquay Natural History Society, 13: 3-28.

Waltham A.C., 2009 - Foundations of Engineering Geology, $3^{\text {rd }}$ edition. Taylor and Francis, New York, 98 p.

Waples D.W. \& Waples J.S., 2004 - A review and evaluation of specific heat capacities of rocks, minerals and subsurface fluids. Part 1: Minerals and nonporous rocks. Natural Resources Research, 13 (2): 97-122.

http://dx.doi.org/10.1023/B:NARR. $\underline{0000032647.41046 . e 7}$ 